\title{
Sesquiterpenoids and 2-(2-Phenylethyl)chromone Derivatives from the Resinous Heartwood of Aquilaria sinensis
}

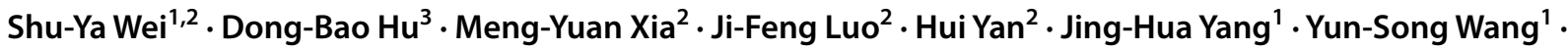 \\ Yue-Hu Wang ${ }^{2}(\mathbb{0}$
}

Received: 8 April 2021 / Accepted: 24 May 2021 / Published online: 1 June 2021

(c) The Author(s) 2021

\begin{abstract}
One novel spirolactone, aquilarisinolide (1), three new sesquiterpenoids, $(2 R, 4 S, 5 R, 7 R)$-2-hydroxyeremophila-9,11-dien8-one (2), $(1 R, 4 S, 5 S, 7 R, 11 R)$-13-hydroxyepidaphnauran-9-en-8-one (3), and (4R,5S,7R,8S,10S,13R)-8,13-dihydroxyrotunda1,11-dien-3-one (4), together with 13 known compounds (5-17) were isolated from the resinous heartwood of Aquilaria sinensis (Thymelaeaceae). The structures of the new compounds were elucidated based on the analysis of NMR and MS data and theoretical calculations their ECD spectra. The isolated compounds were evaluated for their protective activities against PC12 cell injury induced by corticosterone (CORT) and 1-methyl-4-phenylpyridine ion ( $\mathrm{MPP}^{+}$), as well as inhibitory activities against BACE1. Compound 4, 5,6-dihydroxy-2-(2-phenylethyl)chromone (5), daphnauranol B (7), 6-methoxy2-[2-(3-methyoxyphenyl)ethyl]chromone (10), isoagarotetrol (14), and 1-hydroxy-1,5-diphenylpentan-3-one (16) showed significant protective effects on CORT-induced injury in PC12 cells at a concentration of $20 \mu \mathrm{M}(P<0.001)$. Isoagarotetrol (14) showed a significant protective effect on $\mathrm{MPP}^{+}$-induced injury in $\mathrm{PC} 12$ cells at a concentration of $20 \mu \mathrm{M}(P<0.001)$, while compound 4 showed a moderate activity $(P<0.01)$. The BACE1-inhibitory activities of all tested compounds were very weak with less than $30 \%$ inhibition at a concentration of $20 \mu \mathrm{M}$.
\end{abstract}

Shu-Ya Wei and Dong-Bao Hu contributed equally to this work.

Yun-Song Wang

wangys@ynu.edu.cn

$\triangle$ Yue-Hu Wang

wangyuehu@mail.kib.ac.cn

1 Key Laboratory of Medicinal Chemistry for Natural Resource, Ministry of Education, School of Chemical Science and Technology, School of Pharmacy, Yunnan University, Kunming 650091, People's Republic of China

2 Key Laboratory of Economic Plants and Biotechnology, Yunnan Key Laboratory for Wild Plant Resources, and State Key Laboratory of Phytochemistry and Plant Resources in West China, Chinese Academy of Sciences, Kunming 650201, People's Republic of China

3 School of Chemical Biology and Environment, Yuxi Normal University, Yuxi 653100, People's Republic of China 


\section{Graphic Abstract}

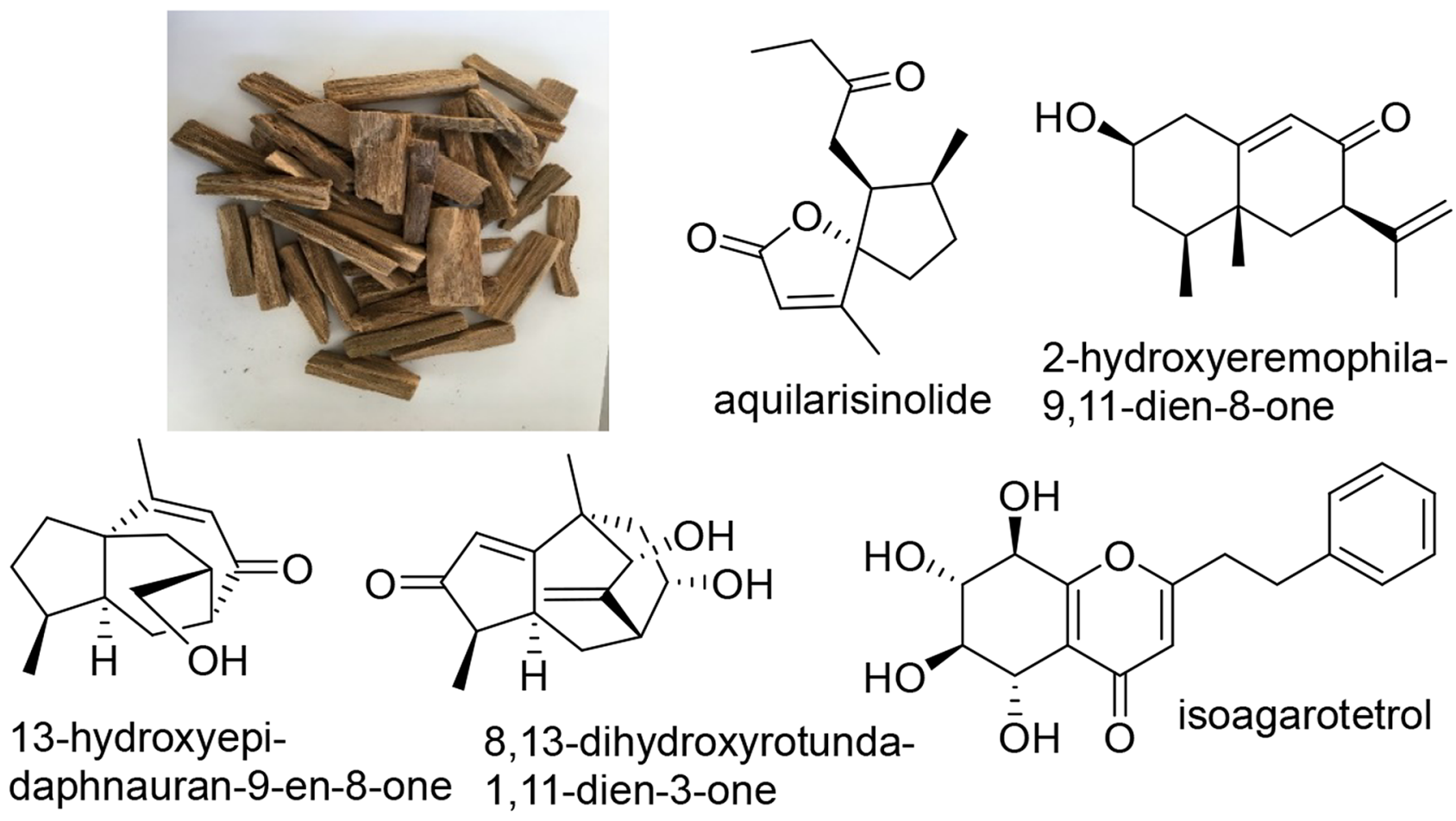

Keywords Thymelaeaceae $\cdot$ Aquilaria sinensis $\cdot$ Sesquiterpenoids $\cdot 2$-(2-phenylethyl)chromones $\cdot$ Neuroprotective

\section{Introduction}

The resinous heartwood of Aquilaria sinensis (Lour.) Spreng. (Thymelaeaceae) is known as agarwood (chen-xiang in Chinese). Chen-xiang, a traditional Chinese medicine, is used to treat thoraco-abdominal distension and pain (xiongfu zhang-men teng-tong), vomiting and hiccups due to stomach cold (wei-han ou-tu e-ni), and asthma due to kidney deficiency (shen-xu qi-ni chuan-ji) [1]. The major chemical constituents from Aquilaria plants are sesquiterpenoids and chromones [2-4]. The fractions and components from agarwood and Aquilaria trees show various pharmacological activities, such as neural activity, gastrointestinal regulation, cytotoxicity, analgesic effects, and antibacterial, antifungal, anti-inflammatory, antiasthmatic, anti-diabetic, and antioxidant activities [4].

In a previous study, we reported several neuroprotective compounds from the resinous heartwood of $A$. sinensis with the origin in Guangdong, China. One hexahydrochromone and three sesquiterpenoids exert significant protective effects on rat adrenal pheochromocytoma (PC12) cell injury induced by corticosterone (CORT), while the hexahydrochromone and one sesquiterpenoid exhibit significant protective effects on 1-methyl-4-phenylpyridine ion $\left(\mathrm{MPP}^{+}\right)$-induced
PC12 cell injury. All of these compounds from the plant are inactive against beta-site amyloid precursor protein cleaving enzyme 1 (BACE1) [5]. In this paper, the isolation and structural elucidation of 17 compounds (1-17, Fig. 1), including four new compounds (1-4), from chen-xiang with the origin in Hainan, China, along with bioassay results in the models of CORT-induced and $\mathrm{MPP}^{+}$-induced PC12 cell damage and BACE1 inhibition, are reported.

\section{Results and Discussion}

\subsection{Structural Elucidation}

The molecular formula of aquilarisinolide (1) was determined to be $\mathrm{C}_{14} \mathrm{H}_{20} \mathrm{O}_{3}$ based on ${ }^{13} \mathrm{C}$ NMR data (Table 1) and the positive ion at $\mathrm{m} / z 259.1307[\mathrm{M}+\mathrm{Na}]^{+}$(calcd for $\left.\mathrm{C}_{14} \mathrm{H}_{20} \mathrm{NaO}_{3}, 259.1310\right)$ in the HRESIMS. The NMR data (Table 1$)$ indicated the presence of one carbonyl group $\left(\delta_{\mathrm{C}}\right.$ $209.0)$, one $\alpha, \beta$-unsaturated $\gamma$-lactone $\left[\delta_{\mathrm{H}} 5.79(\mathrm{br} \mathrm{s}) ; \delta_{\mathrm{C}}\right.$ 172.0, 169.0, 118.8, and 99.4] [6], three methyl groups $\left[\delta_{\mathrm{H}}\right.$ $2.07(\mathrm{~s}), 1.04(\mathrm{t}, J=7.5 \mathrm{~Hz})$, and $0.84(\mathrm{~d}, J=7.2 \mathrm{~Hz}) ; \delta_{\mathrm{C}}$ $15.5,15.3$, and 8.0], four methylenes, and two methines. Based on the COSY correlations (Fig. 2), two connections, 


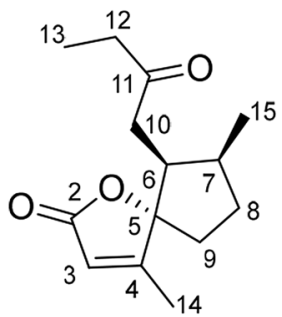

1

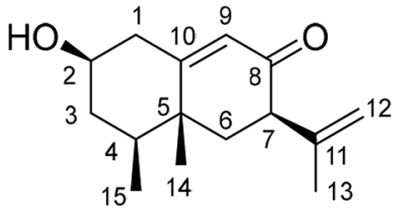

2

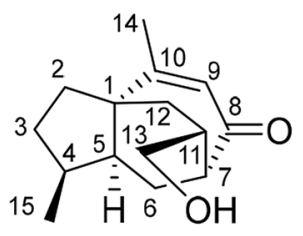

3

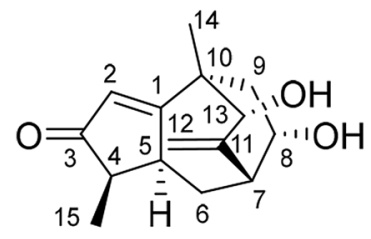

4

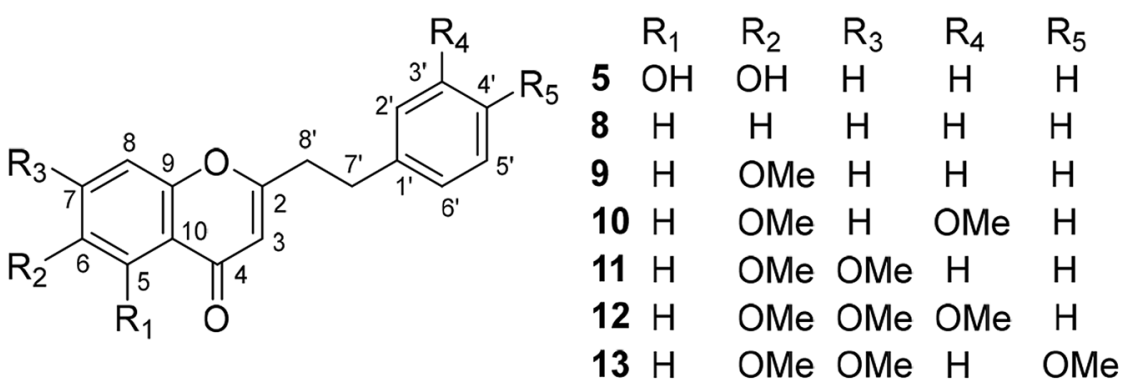<smiles>[R]C1c2c(oc(CCc3ccccc3)cc2=O)[C@@H](O)C([R2])[C@H]1O</smiles>

$14 \mathrm{R}_{1}=\beta-\mathrm{OH}, \mathrm{R}_{2}=\mathrm{OH}$ $15 \mathrm{R}_{1}=\alpha-\mathrm{OH}, \mathrm{R}_{2}=\mathrm{Cl}$

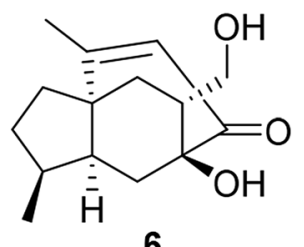

6

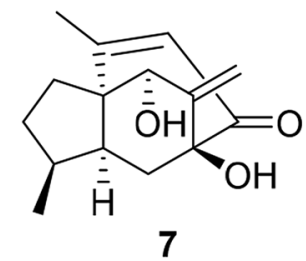

7<smiles>O=C(CCc1ccccc1)CC(O)c1ccccc1</smiles>

16<smiles>O=C(CC(O)CCc1ccccc1)c1ccccc1</smiles>

17

Fig. 1 Chemical structures of compounds 1-17

C-9-C-8-C-7-(C-15)-C-6-C-10 and C-12-C-13 were deduced. Through its HMBC spectrum, correlations from $\mathrm{H}_{3}-14$ to $\mathrm{C}-3, \mathrm{C}-4$, and C-5, from $\mathrm{H}-3$ to $\mathrm{C}-2$ and C-5, from $\mathrm{H}_{2}-8$ and $\mathrm{H}_{2}-10$ to $\mathrm{C}-5$, from $\mathrm{H}-6$ to $\mathrm{C}-11$, and from $\mathrm{H}_{3}-13$ to $\mathrm{C}-11$ (Fig. 2) were observed. Combining these 2D NMR correlations and the HRESIMS, the planar structure of $\mathbf{1}$, with a spiro ring system, was deduced to be 4,7-dimethyl6-(2-oxobutyl)-1-oxaspiro[4.4]non-3-en-2-one. The relative configuration of $\mathbf{1}$ was deduced from its ROESY spectrum. $\mathrm{H}-6$ was first assumed to be $\alpha$-oriented; thus, the C- $6-\mathrm{C}-10$ bond should be $\beta$-oriented. Based on the ROESY correlations of $\mathrm{H}_{3}-14 / \mathrm{H}_{2}-10$ and $\mathrm{H}_{3}-15 / \mathrm{H}_{2}-10$, the C-4-C-5 bond and 7-Me should be $\beta$-oriented, and thus, the $\mathrm{C}-5-\mathrm{O}$ bond, $\mathrm{H}-6$, and $\mathrm{H}-7$ should be $\alpha$-oriented.

According to ${ }^{13} \mathrm{C}$ NMR data (Table 1) and HRESIMS, the molecular formula of compound $\mathbf{2}$ was deduced to be $\mathrm{C}_{15} \mathrm{H}_{22} \mathrm{O}_{2}$. Its NMR data indicated the presence of one terminal double bond $\left[\delta_{\mathrm{H}} 4.90(1 \mathrm{H}, \mathrm{m})\right.$ and $4.71(1 \mathrm{H}, \mathrm{m})$; $\delta_{\mathrm{C}} 145.1$ and 114.1], one $\alpha, \beta$-unsaturated ketone [ $\delta_{\mathrm{H}} 5.79$ $(1 \mathrm{H}, \mathrm{d}, J=1.2 \mathrm{~Hz}) ; \delta_{\mathrm{C}} 202.0,170.1$, and 125.2$]$, three methyl groups $\left[\delta_{\mathrm{H}} 1.75(3 \mathrm{H}, \mathrm{br} \mathrm{s}), 1.12(3 \mathrm{H}, \mathrm{s})\right.$, and $0.98(3 \mathrm{H}, \mathrm{d}$, $J=6.7 \mathrm{~Hz})]$, three methylenes, three methines including one oxygenated group $\left[\delta_{\mathrm{H}} 3.57(1 \mathrm{H}, \mathrm{m}) ; \delta_{\mathrm{C}} 72.3\right]$, and one quaternary carbon $\left(\delta_{\mathrm{C}} 40.7\right)$. Two fragments of C-1-C-2-C-3-C4-C-15 and C-6-C-7 were deduced by correlations (Fig. 2) from its COSY spectrum. Based on the key HMBC correlations from $\mathrm{H}-1$ to $\mathrm{C}-9$, from $\mathrm{H}-9$ to $\mathrm{C}-1$, from $\mathrm{H}_{3}-14$ and C-4, C-5, C-6, and C-10, from $\mathrm{H}_{2}-6$ to C-8 and C-10, and from $\mathrm{H}_{3}-13$ to $\mathrm{C}-7, \mathrm{C}-11$, and C-12, the planar structure of 2 was elucidated as 2-hydroxyeremophila-9,11-dien-8-one with an eremophilane skeleton. In order to deduce the relative configuration of $\mathbf{2}, \mathrm{H}-2$ was assumed to be $\alpha$-oriented. Because a large coupling constant between $\mathrm{H}-2$ and $\mathrm{H}-1 \beta$ $\left(J_{1 \beta, 2}=11.5 \mathrm{~Hz}\right)$ was observed, the orientations of the two protons of $\mathrm{C}-1$ were determined. In the ROESY spectrum of 2 , the correlations of $\mathrm{H}-1 \beta / \mathrm{H}_{3}-14, \mathrm{H}_{3}-14 / \mathrm{H}_{3}-15$, and $\mathrm{H}-4 / \mathrm{H}-7$ were observed. Thus, $4-\mathrm{Me}$ and $5-\mathrm{Me}$ should be $\beta$-oriented and $\mathrm{H}-7$ should be $\alpha$-oriented.

Compound 3 had the molecular formula $\mathrm{C}_{15} \mathrm{H}_{22} \mathrm{O}_{2}$ based on its ${ }^{13} \mathrm{C}$ NMR data (Table 2) and the positive ion at $\mathrm{m} / \mathrm{z}$ $257.1516[\mathrm{M}+\mathrm{Na}]^{+}$(calcd for $\mathrm{C}_{15} \mathrm{H}_{22} \mathrm{NaO}_{2}, 257.1518$ ) in the HRESIMS. The ${ }^{1} \mathrm{H}$ NMR spectrum showed resonances for one trisubstituted double bond $\left[\delta_{\mathrm{H}} 5.90(\mathrm{br} \mathrm{s})\right]$, as well as two methyl groups $\left[\delta_{\mathrm{H}} 2.03(\mathrm{~d}, J=1.2 \mathrm{~Hz})\right.$ and $1.02(\mathrm{~d}$, 
Table $1{ }^{1} \mathrm{H}$ and ${ }^{13} \mathrm{C}$ NMR data of $\mathbf{1}$ and $\mathbf{2}$ ( $\delta$ in ppm, $J$ in $\mathrm{Hz}$ )

\begin{tabular}{|c|c|c|c|c|}
\hline \multirow[t]{2}{*}{ No. } & \multicolumn{2}{|l|}{1 in $\mathrm{CDCl}_{3}$} & \multicolumn{2}{|l|}{2 in methanol- $d_{4}$} \\
\hline & $\delta_{\mathrm{H}}(800 \mathrm{MHz})$ & $\delta_{\mathrm{C}}(201 \mathrm{MHz})$ & $\delta_{\mathrm{H}}(600 \mathrm{MHz})$ & $\delta_{\mathrm{C}}(151 \mathrm{MHz})$ \\
\hline 1 & & & $\begin{array}{l}2.50, \mathrm{ddd}(11.5,5.2, \\
\text { 1.5), } \alpha-\mathrm{H} \\
\text { 2.44, ddd }(11.5,11.5 \text {, } \\
1.3), \beta-\mathrm{H}\end{array}$ & 43.1 \\
\hline 2 & & 172.0 & $3.57, \mathrm{~m}$ & 72.3 \\
\hline 3 & 5.79, br s & 118.8 & $\begin{array}{l}1.86, \mathrm{~m}, \alpha-\mathrm{H} \\
1.51, \mathrm{~m}, \beta-\mathrm{H}\end{array}$ & 40.2 \\
\hline 4 & & 169.0 & $1.84, \mathrm{~m}$ & 36.9 \\
\hline 5 & & 99.4 & & 40.7 \\
\hline 6 & $3.07, \mathrm{~m}$ & 47.2 & $2.01, \mathrm{~m}$ & 38.1 \\
\hline 7 & $2.64, \mathrm{~m}$ & 35.0 & 3.09, dd $(9.9,6.7)$ & 51.6 \\
\hline 8 & $\begin{array}{l}2.16, \mathrm{~m}, \alpha-\mathrm{H} \\
1.53, \mathrm{~m}, \beta-\mathrm{H}\end{array}$ & 32.0 & & 202.0 \\
\hline 9 & $\begin{array}{l}2.07, \mathrm{~m}, \beta-\mathrm{H} \\
1.94, \mathrm{~m}, \alpha-\mathrm{H}\end{array}$ & 34.5 & $5.79, \mathrm{~d}(1.2)$ & 125.2 \\
\hline 10 & $\begin{array}{l}2.44, \mathrm{dd}(17.1,10.7) \\
2.25, \mathrm{dd}(17.1,4.4)\end{array}$ & 38.8 & & 170.1 \\
\hline 11 & & 209.0 & & 145.1 \\
\hline 12 & $2.40, \mathrm{~m}$ & 35.9 & $\begin{array}{l}4.90, \mathrm{~m} \\
4.71, \mathrm{~m}\end{array}$ & 114.1 \\
\hline 13 & $1.04, \mathrm{t}(7.5)$ & 8.0 & 1.75, br s & 20.8 \\
\hline 14 & $2.07, \mathrm{~s}$ & 15.5 & $1.12, \mathrm{~s}$ & 20.4 \\
\hline 15 & $0.84, \mathrm{~d}(7.2)$ & 15.3 & $0.98, \mathrm{~d}(6.7)$ & 16.0 \\
\hline
\end{tabular}
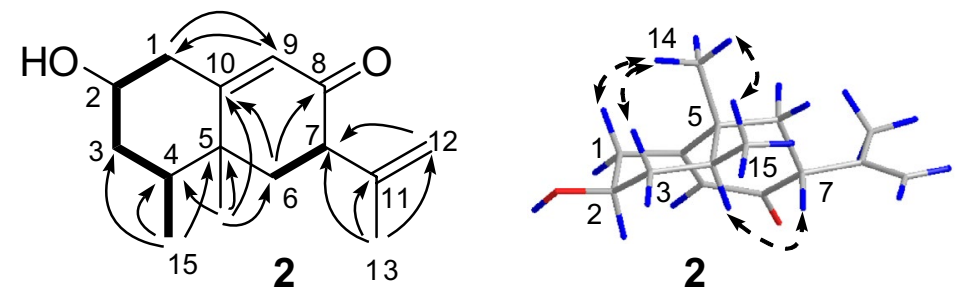

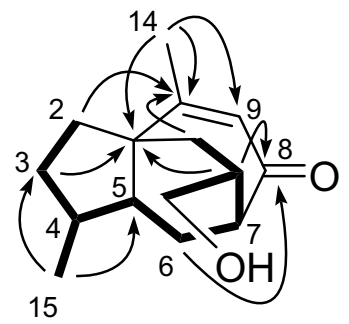

3

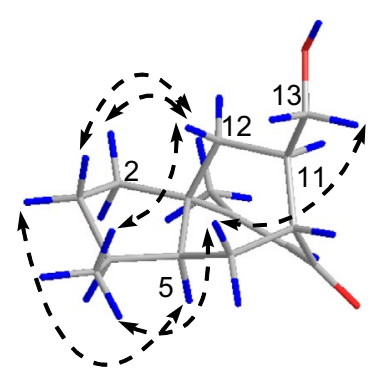

3

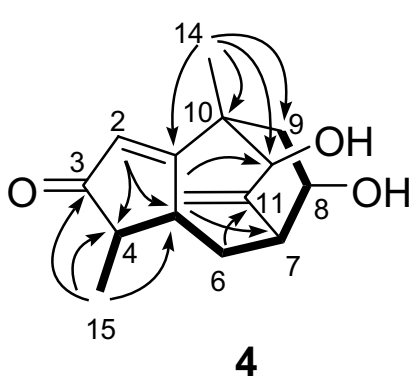

4

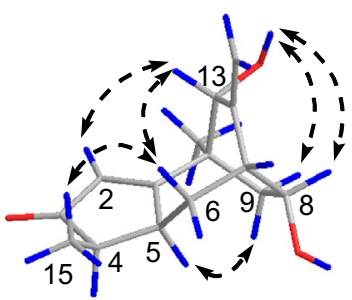

4

\section{COSY}

Fig. 2 Key 2D NMR correlations of compounds 1-4 
Table $2{ }^{1} \mathrm{H}$ and ${ }^{13} \mathrm{C}$ NMR data of $\mathbf{3}$ and $\mathbf{4}(\delta$ in ppm, $J$ in $\mathrm{Hz})$

\begin{tabular}{|c|c|c|c|c|c|c|}
\hline \multirow[t]{2}{*}{ No. } & \multicolumn{2}{|l|}{3 in methanol- $d_{4}$} & \multicolumn{2}{|l|}{4 in DMSO- $d_{6}$} & \multicolumn{2}{|l|}{$4 \mathrm{in} \mathrm{CDCl}_{3}$} \\
\hline & $\delta_{\mathrm{H}}(800 \mathrm{MHz})$ & $\delta_{\mathrm{C}}(201 \mathrm{MHz})$ & $\delta_{\mathrm{H}}(600 \mathrm{MHz})$ & $\delta_{\mathrm{C}}(151 \mathrm{MHz})$ & $\delta_{\mathrm{H}}(500 \mathrm{MHz})$ & $\delta_{\mathrm{C}}(126 \mathrm{MHz})$ \\
\hline 1 & & 53.5 & & 189.7 & & 187.9 \\
\hline 2 & $\begin{array}{l}1.99, \mathrm{~m}, \alpha-\mathrm{H} \\
1.64, \mathrm{~m}, \beta-\mathrm{H}\end{array}$ & 36.3 & $5.94, \mathrm{~d}(1.1)$ & 126.7 & $5.94, d(0.7)$ & 128.2 \\
\hline 3 & $\begin{array}{l}1.85, \mathrm{~m}, \alpha-\mathrm{H} \\
1.41, \mathrm{~m}, \beta-\mathrm{H}\end{array}$ & 34.6 & & 210.7 & & 212.1 \\
\hline 4 & $2.25, \mathrm{~m}$ & 37.1 & $2.48, \mathrm{~m}$ & 43.5 & $2.55, \mathrm{~m}$ & 44.4 \\
\hline 5 & $2.02, \mathrm{~m}$ & 50.9 & $3.40, \mathrm{~m}$ & 41.5 & $3.47, \mathrm{~m}$ & 42.2 \\
\hline 6 & $\begin{array}{l}\text { 1.71, } \mathrm{td}(12.8,2.5), \beta-\mathrm{H} \\
1.50, \mathrm{~m}, \alpha-\mathrm{H}\end{array}$ & 20.1 & $\begin{array}{l}2.36, \mathrm{~m}, \beta-\mathrm{H} \\
0.86, \mathrm{~m}, \alpha-\mathrm{H}\end{array}$ & 35.4 & $\begin{array}{l}2.48, \mathrm{~m}, \beta-\mathrm{H} \\
1.10, \mathrm{~m}, \alpha-\mathrm{H}\end{array}$ & 35.2 \\
\hline 7 & $2.72, \mathrm{~m}$ & 50.2 & $2.62, \mathrm{~m}$ & 43.5 & $2.82, \mathrm{~m}$ & 43.8 \\
\hline 8 & & 209.8 & $4.13, \mathrm{~m}$ & 64.5 & $4.40, \mathrm{~m}$ & 66.9 \\
\hline 9 & 5.90, br s & 130.0 & $\begin{array}{l}1.98, \mathrm{dd}(14.0,10.2), \beta-\mathrm{H} \\
1.55, \mathrm{~m}, \alpha-\mathrm{H}\end{array}$ & 37.7 & $\begin{array}{l}2.26, \mathrm{dd}(14.3,10.3), \beta-\mathrm{H} \\
1.72, \mathrm{dd}(14.3,5.2), \alpha-\mathrm{H}\end{array}$ & 37.7 \\
\hline 10 & & 172.5 & & 42.8 & & 43.0 \\
\hline 11 & $1.87, \mathrm{~m}$ & 37.2 & & 153.6 & & 153.1 \\
\hline 12 & $\begin{array}{l}1.51, \mathrm{~m}, \alpha-\mathrm{H} \\
1.31, \mathrm{dd}(13.5,9.8), \beta-\mathrm{H}\end{array}$ & 31.1 & $\begin{array}{l}4.97 \text {, br s } \\
4.95 \text {, br s }\end{array}$ & 115.9 & $\begin{array}{l}5.11, \text { br s } \\
5.12 \text {, br s }\end{array}$ & 117.7 \\
\hline 13 & $\begin{array}{l}3.52, \mathrm{dd}(10.8,6.0) \\
3.47, \mathrm{dd}(10.8,8.3)\end{array}$ & 64.1 & $3.58, \mathrm{~d}(4.0)$ & 74.0 & 3.82, br s & 75.5 \\
\hline 14 & $2.03, \mathrm{~d}(1.2)$ & 22.5 & $1.17, \mathrm{~s}$ & 24.3 & $1.31, \mathrm{~s}$ & 24.3 \\
\hline 15 & $1.02, \mathrm{~d}(7.2)$ & 17.3 & $0.89, \mathrm{~d}(7.4)$ & 9.9 & $1.05, \mathrm{~d}(7.5)$ & 10.1 \\
\hline $8-\mathrm{OH}$ & & & $4.84, \mathrm{~d}(3.0)$ & & & \\
\hline $13-\mathrm{OH}$ & & & $5.11, \mathrm{~d}(4.0)$ & & & \\
\hline
\end{tabular}

$J=7.2 \mathrm{~Hz}$ )] (Table 2). The ${ }^{13} \mathrm{C}$ NMR spectrum showed resonances for 15 carbon signals indicating the presence of one $\alpha, \beta$-unsaturated ketone $\left(\delta_{\mathrm{C}} 209.8,172.5\right.$, and 130.0), two methyl groups ( $\delta_{\mathrm{C}} 22.5$ and 17.3), five methylenes including one oxygenated group $\left(\delta_{\mathrm{C}} 64.1\right)$, four methines, and one quaternary carbon atom $\left(\delta_{\mathrm{C}} 53.5\right)$. By comparing its NMR data with those of daphnauranol A (6) and daphnauranol B (7) [7], compound 3 was deduced to be this type of sesquiterpenoid.

From the COSY correlations of 3 (Fig. 2), one moiety of C-2-C-3-C-4-(C-15)-C-5-C-6-C-7-C-11-(C-13)-C-12 was elucidated. According to the HMBC correlations (Fig. 2) from $\mathrm{H}-2$ to $\mathrm{C}-10$, from $\mathrm{H}-3$ to $\mathrm{C}-1$, from $\mathrm{H}_{3}-15$ to $\mathrm{C}-3$ and C-5, from $\mathrm{H}_{2}-6$ to $\mathrm{C}-8$, from $\mathrm{H}-11$ to $\mathrm{C}-1$ and $\mathrm{C}-8$, from $\mathrm{H}_{2}-12$ to $\mathrm{C}-10$, and from $\mathrm{H}_{3}-14$ to $\mathrm{C}-1, \mathrm{C}-9$, and $\mathrm{C}-10$, the planar structure of $\mathbf{3}$ with a 5/6/7 ring system was elucidated as shown in Fig. 2. Its structure was very similar to that of daphnauranol A, except for the lack of a hydroxy group at $\mathrm{C}-7$ in 3 . In the ROESY spectrum of $\mathbf{3}$, correlations of $\mathrm{H}-2 \beta / \mathrm{H}-12 \beta, \mathrm{H}-3 \beta / \mathrm{H}-12 \beta, \mathrm{H}_{3}-15 / \mathrm{H}-6 \beta, \mathrm{H}_{3}-15 / \mathrm{H}-12 \beta, \mathrm{H}-6 \beta /$ $\mathrm{H}_{2}-13$, and $\mathrm{H}-3 \alpha / \mathrm{H}-5$ were observed. The relative configuration of $\mathbf{3}$ was deduced to be 13-hydroxydaphnauran-9-en8-one as shown in Fig. 2.
Compound 4 was assigned the molecular formula $\mathrm{C}_{15} \mathrm{H}_{20} \mathrm{O}_{3}$, as determined by ${ }^{13} \mathrm{C}$ NMR data (Table 2) and the positive ion at $\mathrm{m} / z 271.1314[\mathrm{M}+\mathrm{Na}]^{+}$(calcd for $\mathrm{C}_{15} \mathrm{H}_{20} \mathrm{NaO}_{3}, 271.1310$ ) in the HRESIMS. The IR spectrum showed absorption bands for hydroxy groups $\left(3424 \mathrm{~cm}^{-1}\right)$, an $\alpha, \beta$-unsaturated ketone $\left(1687 \mathrm{~cm}^{-1}\right)$, and an exocyclic double bond $\left(3071 \mathrm{~cm}^{-1}\right)$. The ${ }^{1} \mathrm{H}$ and ${ }^{13} \mathrm{C}$ NMR data in DMSO- $d_{6}$ (Table 2) indicated the presence of one $\alpha, \beta$ unsaturated ketone $\left[\delta_{\mathrm{H}} 5.94(\mathrm{~d}, J=1.1 \mathrm{~Hz}) ; \delta_{\mathrm{C}} 210.7,189.7\right.$, and 126.7], one exocyclic double bond [ $\delta_{\mathrm{H}} 4.97$ (br s) and 4.95 (br s); $\delta_{\mathrm{C}} 153.6$ and 115.9 ], two methyl groups [ $\delta_{\mathrm{H}} 1.17$ (s) and $0.89(\mathrm{~d}, J=7.4 \mathrm{~Hz}) ; \delta_{\mathrm{C}} 22.5$ and 17.3], two methylenes, five methines including two oxygenated groups $\left[\delta_{\mathrm{H}}\right.$ $4.13(\mathrm{~m})$ and $3.58(\mathrm{~d}, J=4.0 \mathrm{~Hz}) ; \delta_{\mathrm{C}} 74.0$ and 64.5), one quaternary carbon atom $\left(\delta_{\mathrm{C}} 42.8\right)$, and two hydroxy groups $\left[\delta_{\mathrm{H}} 5.11(\mathrm{~d}, J=4.0 \mathrm{~Hz})\right.$ and $\left.4.84(\mathrm{~d}, J=3.0 \mathrm{~Hz})\right]$. According to the COSY correlations (Fig. 2), a fragment comprising of C-15-C-4-C-5-C-6-C-7-C-8-C-9 was deduced. By key HMBC correlations from $\mathrm{H}-2$ to $\mathrm{C}-4$ and $\mathrm{C}-5$, from $\mathrm{H}_{3}-15$ to C-3 and C-5, from $\mathrm{H}_{2}-6$ to C-11, from $\mathrm{H}-12$ to $\mathrm{C}-7$ and C-13, and from $\mathrm{H}_{3}-14$ to $\mathrm{C}-1, \mathrm{C}-9, \mathrm{C}-10$, and $\mathrm{C}-13$, compound 4 was elucidated to be 8,13-dihydroxyrotunda-1,11-dien3 -one, with a very rare tricyclic rotundane skeleton. The relative configuration of $\mathbf{4}$ was deduced from its ROESY 
spectrum. The ROESY correlations (Fig. 2) of $\mathrm{H}_{3}-15 / \mathrm{H}-6 \beta$ and $\mathrm{H}-6 / \mathrm{H}-13$ indicated that $13-\mathrm{OH}$ should be $\alpha$-oriented; the ROESY correlations of $13-\mathrm{OH} / \mathrm{H}-8,13-\mathrm{OH} / \mathrm{H}-9 \beta$, and $\mathrm{H}-5 / \mathrm{H}-9 \alpha$ indicated that $8-\mathrm{OH}$ and $\mathrm{H}-5$ should also be $\alpha$-oriented.

The absolute configurations of $\mathbf{1 - 4}$ were determined to be $5 S, 6 S, 7 S-\mathbf{1}, 2 R, 4 S, 5 R, 7 R-\mathbf{2}, 1 R, 4 S, 5 S, 7 R, 11 R-\mathbf{3}$, and $4 R$, $5 S, 7 R, 8 S, 10 S, 13 R-4$ (Fig. 1), by comparison of the experimental electronic circular dichroism (ECD) spectra with the theoretical results (Fig. 3).

5,6-Dihydroxy-2-(2-phenylethyl)chromone (5) was recently reported with NMR data measured in $\mathrm{CDCl}_{3}$ [8]. Its NMR data in methanol- $d_{4}$ are shown in Table 3 . The structure of 6,7-dimethoxy-2-[2-(3-methoxyphenyl) ethyl]chromone (12) was found in the SciFinder database. However, no literature was provided in the database. The NMR data of $\mathbf{1 2}$ are presented in this paper (Table 3). The relative configuration of compound $\mathbf{1 5}$ has been
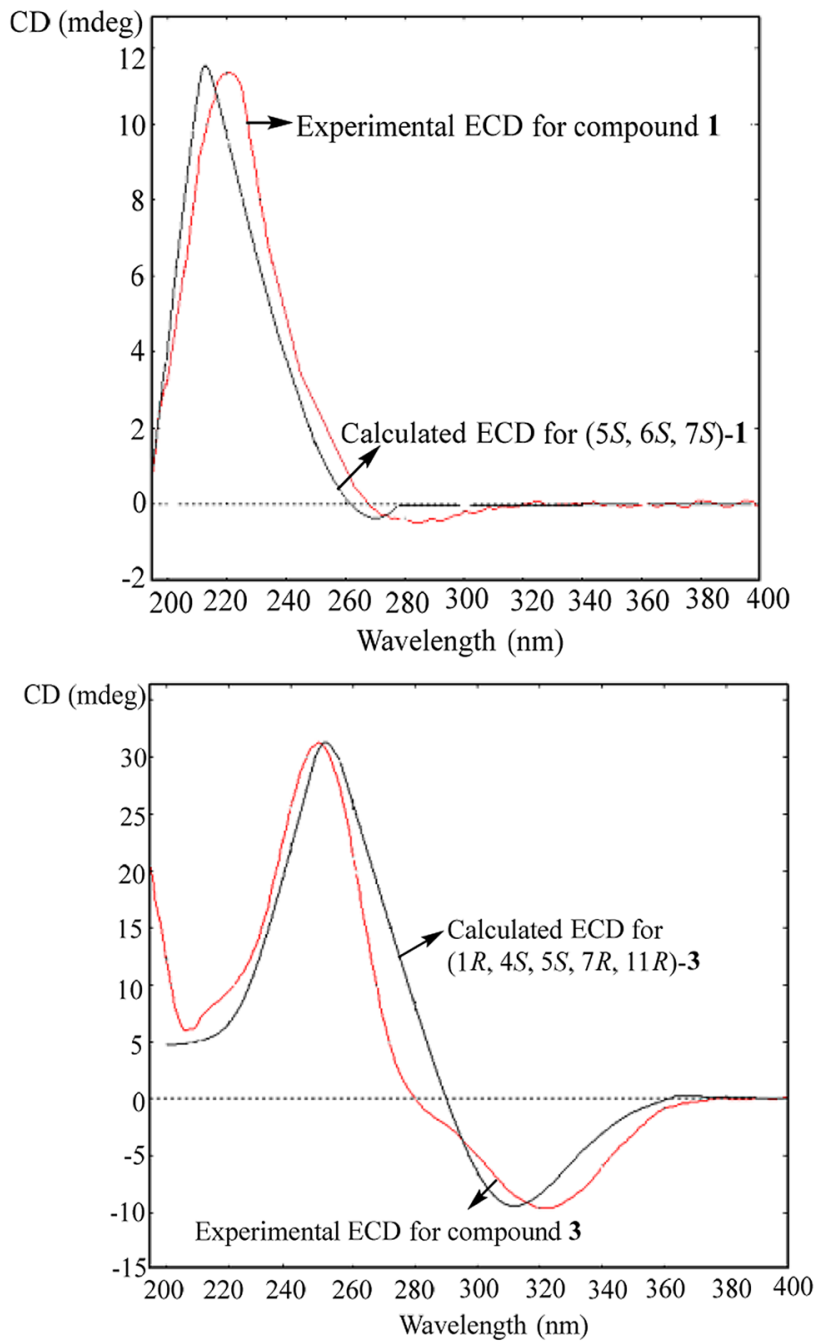

reported [9]. Its absolute configuration was determined to be $(5 S, 6 S, 7 S, 8 R)$-8-chloro-2-(2-phenylethyl)-5,6,7-trihydroxy-5,6,7,8-tetrahydrochromone by ECD calculations (Supplementary Material, Fig. S39). Daphnauranol A (6) [7], daphnauranol B (7) [7], 2-(2-phenylethyl)chromone (8) [10], 6-methoxy-2-(2-phenylethyl)chromone (9) [11], 6-methoxy-2-[2-(3-methyoxyphenyl)ethyl]chromone (10) [11], 6,7-dimethoxy-2-(2-phenylethyl)chromone (11) [11], 6,7-dimethoxy-2-[2-(4-methoxyphenyl)ethyl]chromone (13) [12], isoagarotetrol (14) [13], 1-hydroxy-1,5-diphenylpentan-3-one(16) [14], and 3-hydroxy-1,5-diphenylpentan-1-one (17) [14] were determined by comparing their obtained spectroscopic data with those reported in the literature.
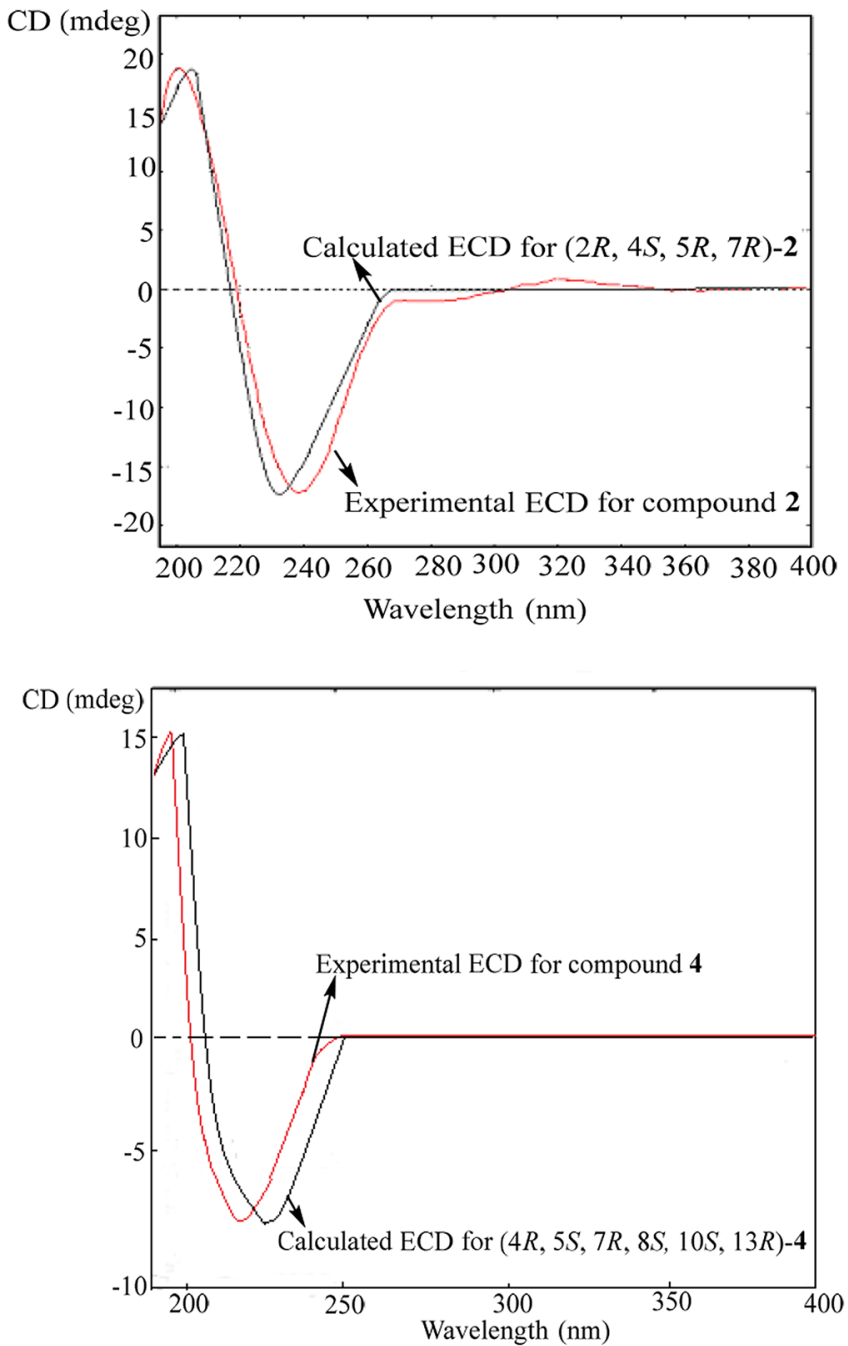

Fig. 3 Experimental and computed ECD spectra of 1-4 
Table $3{ }^{1} \mathrm{H}$ and ${ }^{13} \mathrm{C}$ NMR data of 5 and $\mathbf{1 2}$ in methanol- $d_{4}(\delta$ in ppm, $J$ in $\mathrm{Hz}$ )

\begin{tabular}{|c|c|c|c|c|}
\hline \multirow[t]{2}{*}{ No. } & \multicolumn{2}{|l|}{5} & \multicolumn{2}{|l|}{12} \\
\hline & $\delta_{\mathrm{H}}(500 \mathrm{MHz})$ & $\delta_{\mathrm{C}}(126 \mathrm{MHz})$ & $\delta_{\mathrm{H}}(800 \mathrm{MHz})$ & $\delta_{\mathrm{C}}(201 \mathrm{MHz})$ \\
\hline 2 & & 172.1 & & 170.7 \\
\hline 3 & $6.05, \mathrm{~s}$ & 109.5 & $6.11, \mathrm{~s}$ & 110.1 \\
\hline 4 & & 185.1 & & 179.9 \\
\hline 5 & & 146.3 & $7.45, \mathrm{~s}$ & 104.9 \\
\hline 6 & & 138.8 & & 149.4 \\
\hline 7 & $7.13, \mathrm{~d}(8.5)$ & 123.0 & & 156.7 \\
\hline 8 & $6.59, \mathrm{~d}(8.5)$ & 111.1 & $7.14, \mathrm{~s}$ & 101.1 \\
\hline 9 & & 153.4 & & 154.5 \\
\hline 10 & & 111.7 & & 117.4 \\
\hline $1^{\prime}$ & & 141.3 & & 142.9 \\
\hline $2^{\prime}$ & $7.23, \mathrm{~m}$ & 129.5 & 6.78 , br s & 115.1 \\
\hline $3^{\prime}$ & $7.25, \mathrm{~m}$ & 129.6 & & 161.3 \\
\hline $4^{\prime}$ & $7.16, \mathrm{~m}$ & 127.5 & $6.75, \mathrm{dd}(8.1,2.3)$ & 112.9 \\
\hline $5^{\prime}$ & $7.25, \mathrm{~m}$ & 129.6 & $7.17, \mathrm{dd}(8.1,7.6)$ & 130.6 \\
\hline $6^{\prime}$ & $7.23, \mathrm{~m}$ & 129.5 & 6.79, br d (7.6) & 121.7 \\
\hline $7^{\prime}$ & 3.09 , br t (7.2) & 33.8 & $3.06, \mathrm{t}(7.5)$ & 34.1 \\
\hline $8^{\prime}$ & 3.00 , br t (7.2) & 37.0 & $3.00, \mathrm{t}(7.5)$ & 36.9 \\
\hline 6-OMe & & & $3.91, \mathrm{~s}$ & 56.6 \\
\hline 7-OMe & & & $3.97, \mathrm{~s}$ & 57.0 \\
\hline 3'-OMe & & & $3.72, \mathrm{~s}$ & 55.5 \\
\hline
\end{tabular}

\subsection{Neuroprotective Activities}

CORT-induced PC12 cell damage is used as an in vitro experimental model for depression studies $[15,16]$, while $\mathrm{MPP}^{+}$has been widely used as a neurotoxin to induce Parkinson's disease (PD) symptoms in cells or rodents' models $[17,18]$. Additionally, BACE1 plays a critical role in Alzheimer's disease (AD) pathophysiology and thus, BACE1 inhibition is considered to be a therapeutic approach for AD [19].

Compounds 1-12 and 14-17 were evaluated for their protective activities against $\mathrm{PC} 12$ cell injury induced by CORT and $\mathrm{MPP}^{+}$and inhibitory activities against BACE1. Compound $\mathbf{1 3}$ was not evaluated for all activities due to an insufficient amount. The results are presented in Table 4. Compared with the negative control, compounds 4, 5, 7, 10, 14, and 16 showed significant protective effects on CORT-induced injury in PC12 cells at a concentration of $20 \mu \mathrm{M}(P<0.001)$, while compounds 3 and $\mathbf{1 1}$ showed weak protective activities $(P<0.05)$. Other tested compounds were inactive $(P>0.05)$. Compared with the negative control, compound $\mathbf{1 4}$ showed a significant protective effect on $\mathrm{MPP}^{+}$-induced injury in PC12 cells at a concentration of $20 \mu \mathrm{M}(P<0.001)$; compound 4 showed a moderate effect on $\mathrm{MPP}^{+}$-induced injury in $\mathrm{PC} 12$ cells at a concentration of $20 \mu \mathrm{M}(P<0.01)$; and compound 16 showed a weak protective activity $(P<0.05)$. Other tested compounds were inactive $(P>0.05)$. The BACE1inhibitory activities of all tested compounds were very weak with inhibition less than $30 \%$ at a concentration of $20 \mu \mathrm{M}$, compared with the positive control LY2886721 with $75.39 \%$ inhibition at a concentration of $0.2 \mu \mathrm{M}$.

\section{Experimental Section}

\subsection{General Experimental Procedures}

Optical rotations were recorded using a JASCO P-1020 polarimeter (Jasco Corp., Tokyo, Japan). UV spectra were recorded on a Shimadzu UV-2401 PC spectrophotometer (Shimadzu, Kyoto, Japan). Electronic circular dichroism (ECD) spectra were recorded on a Chirascan CD spectrometer (Applied Photophysics Ltd., Leatherhead, UK). IR spectra were measured on a Bruker Tensor 27 FTIR Spectrometer (Bruker Corp., Ettlingen, Germany) with $\mathrm{KBr}$ disks. ${ }^{1} \mathrm{H}$ and ${ }^{13} \mathrm{C}$ NMR spectra were collected on Bruker DRX-500, Avance III-600, and Ascend ${ }^{\mathrm{TM}} 800 \mathrm{MHz}$ NMR spectrometers (Bruker Corporation, Karlsruhe, Germany), with TMS as an internal standard. ESIMS and 
Table 4 The effects of compounds from A. sinensis on PC12 cell injury induced by corticosterone and MPP ${ }^{+}$and on BACE1 inhibition ${ }^{\mathrm{a}}$

\begin{tabular}{|c|c|c|c|}
\hline \multirow[t]{2}{*}{ Compound } & $\begin{array}{l}\text { PC12 cell injury induced by } \\
\text { corticosterone }\end{array}$ & PC12 cell injury induced by $\mathrm{MPP}^{+}$ & BACE1 inhibition \\
\hline & Survival rate $\pm \mathrm{SD}(\%)^{\mathrm{b}}$ & Survival rate $\pm \operatorname{SD}(\%)^{\mathrm{b}, \mathrm{c}}$ & Inhibition rate $\pm \mathrm{SD}(\%)$ \\
\hline 1 & $59.71 \pm 1.52$ & $70.63 \pm 1.85$ & $20.33 \pm 0.32$ \\
\hline 2 & $59.15 \pm 1.26$ & $69.77 \pm 0.60$ & $6.64 \pm 0.40$ \\
\hline 3 & $62.40 \pm 0.90 *$ & $69.42 \pm 2.73$ & $21.62 \pm 1.03$ \\
\hline 4 & $80.20 \pm 1.97 * * *$ & $73.52 \pm 1.25 * *$ & $20.45 \pm 0.48$ \\
\hline 5 & $78.71 \pm 2.03 * * *$ & $72.06 \pm 3.22$ & $16.25 \pm 0.37$ \\
\hline 6 & $59.74 \pm 1.02$ & $69.53 \pm 1.17$ & $9.43 \pm 0.12$ \\
\hline 7 & $72.56 \pm 2.05 * * *$ & $72.66 \pm 1.11$ & $6.84 \pm 0.56$ \\
\hline 8 & $59.62 \pm 2.12$ & $71.09 \pm 0.65$ & $18.65 \pm 0.85$ \\
\hline 9 & $60.35 \pm 2.64$ & $72.68 \pm 3.00$ & $0.19 \pm 0.29$ \\
\hline 10 & $73.73 \pm 1.11 * * *$ & $72.51 \pm 2.12$ & $26.55 \pm 1.11$ \\
\hline 11 & $64.94 \pm 2.27 *$ & $68.62 \pm 2.96$ & $26.86 \pm 0.17$ \\
\hline 12 & $63.80 \pm 2.55$ & $67.58 \pm 1.53$ & $7.19 \pm 0.56$ \\
\hline 14 & $79.45 \pm 0.95 * * *$ & $74.89 \pm 0.57 * * *$ & $16.55 \pm 1.38$ \\
\hline 15 & $59.69 \pm 1.07$ & $71.88 \pm 2.79$ & $18.84 \pm 0.66$ \\
\hline 16 & $71.76 \pm 2.27 * * *$ & $74.83 \pm 2.15^{*}$ & $9.78 \pm 0.25$ \\
\hline 17 & $60.70 \pm 2.51$ & $71.22 \pm 1.42$ & $18.67 \pm 0.45$ \\
\hline desipramine (positive control) & $89.66 \pm 0.78 * * *$ & - & - \\
\hline negative control & $59.92 \pm 0.33$ & $69.72 \pm 1.77$ & - \\
\hline blank & $100.00 \pm 0.22$ & $100 \pm 1.04$ & - \\
\hline vitamin E (positive control) & - & $75.70 \pm 0.64 * * *$ & \\
\hline LY2886721 (positive control) & - & - & $75.39 \pm 0.82$ \\
\hline
\end{tabular}

${ }^{a}$ The concentration of the tested compounds was $20 \mu \mathrm{M}$; the concentrations of desipramine, vitamin E, and LY2886721 were $10 \mu \mathrm{M}, 0.2 \mu \mathrm{M}$, and $0.2 \mu \mathrm{M}$, respectively

${ }^{\mathrm{b}}$ Compared with the negative control, $* P<0.05$, $* * P<0.01$, *** $P<0.001$

${ }^{\mathrm{c}}$ For compounds 5, 7-10, and 16, the negative control was $69.05 \pm 0.49 \%$ and the blank was $100 \pm 0.98 \%$; For compound 12, the negative control was $67.66 \pm 1.26 \%$ and the blank was $100 \pm 0.98 \%$

HRESIMS analyses were performed on an API QSTAR Pulsar 1 spectrometer (Applied Biosystems/MDS Sciex, Foster City, CA, USA). Silica gel G (80-100 and 300-400 mesh, Qingdao Meigao Chemical Co., Ltd., Qingdao, China), $\mathrm{C}_{18}$ silica gel (40-75 $\mu \mathrm{m}$, Fuji Silysia Chemical Ltd., Aichi, Japan), and Sephadex LH-20 (GE Healthcare Bio-Sciences AB, Uppsala, Sweden) were used for column chromatography. Thin-layer chromatography (TLC) spots were visualized under UV light at $254 \mathrm{~nm}$ and by dipping in $5 \% \mathrm{H}_{2} \mathrm{SO}_{4}$ in alcohol followed by heating. Semipreparative high-performance liquid chromatography (HPLC) was performed on an Agilent 1200 series pump (Agilent Technologies, Santa Clara, USA) equipped with a diode array detector, a Welch Ultimate AQ- $\mathrm{C}_{18}$ column ( $5 \mu \mathrm{m}, \phi 7.8 \times 250 \mathrm{~mm}$, Welch Materials Inc., Shanghai, China), an Agilent Zorbax SB-C ${ }_{18}$ column $(5.0 \mu \mathrm{m}, \phi$ $9.4 \times 250 \mathrm{~mm})$, and a chiral-phase CD-Ph column $(5.0 \mu \mathrm{m}$, $\phi 4.6 \times 250 \mathrm{~mm}$; Shiseido, Japan). The absorbance from the MTS assay was measured by a Thermo Multiskan FC microplate reader (Waltham, MA, USA). The fluorescence values in the BACE1-inhibitory activity assay were read by a FlexStation 3 Multi-Mode microplate reader (Molecular Devices, San Jose, CA, USA). Desipramine was purchased from Beijing Pujing Kangli Technology Co., Ltd. (Beijing, China); corticosterone, penicillin, streptomycin, MTS, $\mathrm{MPP}^{+}$, and the BACE1 kit were purchased from Sigma; MTS was purchased from Promega; DMEM, FBS, and PBS were obtained from Biofluids Inc. (Rockville, MD, USA); and LY2886721 (CAS No. 1262036-50-9) was from Shanghai Lanmu Chemical Co., Ltd. (Shanghai, China).

\subsection{Plant Material}

The resinous heartwood of $A$. sinensis with the origin in Hainan, China was purchased from Xiamen Yanlaifu Pharmaceutical Co., Ltd., China (production lot number 140303), in December, 2017. The plant material was also identified by Prof. Shu-De Yang, at Yunnan University of Traditional Chinese Medicine, China. A voucher specimen (no. HN140303) 
was deposited at the Yunnan Key Laboratory for Wild Plant Resources, Kunming Institute of Botany, Chinese Academy of Sciences.

\subsection{Extraction and Isolation}

The resinous heartwood of A. sinensis $(0.5 \mathrm{~kg})$ was ground into a powder and ultrasonically extracted with $95 \% \mathrm{EtOH}$ at $60{ }^{\circ} \mathrm{C}$ for half an hour. The extract was subjected to reduced pressure evaporation to yield a gum $(53.8 \mathrm{~g})$. The gum was dissolved in water and extracted successively with petroleum ether, EtOAc, and $n$-BuOH to yield fractions A (0.6 g), B (36.4 g), and C (14.7 g), respectively.

Fraction B was subjected to silica gel column chromatography $(\mathrm{CC}$, petroleum ether-EtOAc, 50:1 $\rightarrow 0: 1$, $\mathrm{v} / \mathrm{v})$ to yield four main fractions (B1-B4). Fraction B 1 was subjected to reversed-phase $\mathrm{C}_{18}\left(\mathrm{RP}-\mathrm{C}_{18}\right)$ silica gel $\mathrm{CC}$ with $\mathrm{MeOH}-\mathrm{H}_{2} \mathrm{O}(10 \% \rightarrow 100 \%)$ to afford four main subfractions B1-1 to B1-4. Subfraction B1-1 (121.8 mg) was subjected to SephadexLH-20 CC (MeOH) to yield subfractions B1-1-1 and B1-1-2. Subfraction B1-1-1 $(87.1 \mathrm{mg}$ ) was purified by silica gel CC (petroleum etherEtOAc, 15:1) to yield 7 (17.6 mg). Subfraction B1-1-2 (22.9 $\mathrm{mg}$ ) was purified by semipreparative HPLC (Agilent Zorbax SB-C $18, \mathrm{CH}_{3} \mathrm{CN}-\mathrm{H}_{2} \mathrm{O}, 30: 70,2 \mathrm{~mL} / \mathrm{min}$ ) to yield $1\left(1 \mathrm{mg}, t_{\mathrm{R}}=40.197 \mathrm{~min}\right)$. Subfraction B1-2 (113.7 mg) was separated by silica gel CC (petroleum ether-EtOAc, 50:1) and semipreparative HPLC (Agilent Zorbax SB-C ${ }_{18}$, $\left.\mathrm{MeOH}-\mathrm{H}_{2} \mathrm{O}, 60: 40,2 \mathrm{~mL} / \mathrm{min}\right)$ to yield $16(4.2 \mathrm{mg}$, $\left.t_{\mathrm{R}}=33.431 \mathrm{~min}\right)$ and $\mathbf{1 7}\left(2.6 \mathrm{mg}, t_{\mathrm{R}}=39.728 \mathrm{~min}\right)$. Subfraction B1-3 $(658.2 \mathrm{mg})$ was subjected to Sephadex LH-20 CC (MeOH) to yield $8(192.6 \mathrm{mg})$. Subfraction B1-4 (1.1 g) was subjected to Sephadex LH-20 CC $(\mathrm{MeOH})$ to yield $5(6.0 \mathrm{mg})$ and a mixture $(953.4 \mathrm{mg})$. The mixture was purified by silica gel CC (petroleum ether-EtOAc, 50:1 $\rightarrow 10: 1)$ to yield $\mathbf{9}(25.2 \mathrm{mg})$ and $\mathbf{1 0}$ (44.0 mg).

Fraction $\mathrm{B} 2$ was subjected to $\mathrm{RP}-\mathrm{C}_{18}$ silica gel CC with $\mathrm{MeOH}-\mathrm{H}_{2} \mathrm{O}(10 \% \rightarrow 100 \%)$ to afford $\mathbf{1 1}(15.6 \mathrm{mg})$ recrystallized from $\mathrm{MeOH}$ and two other subfractions, B2-1 and B2-2. Subfraction B2-1 (436.3 mg) was purified by Sephadex LH-20 CC (MeOH) and semipreparative HPLC (Agilent Zorbax SB-C ${ }_{18}, \mathrm{CH}_{3} \mathrm{CN}-\mathrm{H}_{2} \mathrm{O}, 30: 70,2 \mathrm{~mL} / \mathrm{min}$ ) to yield $3\left(1.5 \mathrm{mg}, t_{\mathrm{R}}=47.901 \mathrm{~min}\right), 2\left(2.4 \mathrm{mg}, t_{\mathrm{R}}=40.414 \mathrm{~min}\right)$, and $6\left(1.8 \mathrm{mg}, \mathrm{t}_{\mathrm{R}}=27.272 \mathrm{~min}\right)$. Subfraction B2-2 (3.7 g) was separated by silica gel $\mathrm{CC}\left(\mathrm{CH}_{2} \mathrm{Cl}_{2}\right.$-acetone, 5:1) and semipreparative HPLC (Chiral CD-Ph, MeOH- $\mathrm{H}_{2} \mathrm{O}, 80: 20$, $1 \mathrm{~mL} / \mathrm{min})$ to obtain $12\left(0.6 \mathrm{mg}, t_{\mathrm{R}}=43.207 \mathrm{~min}\right)$ and $\mathbf{1 3}$ $\left(1.2 \mathrm{mg}, t_{\mathrm{R}}=35.603 \mathrm{~min}\right)$.

Fraction B3 was subjected to RP-C18 silica gel CC with $\mathrm{MeOH}-\mathrm{H}_{2} \mathrm{O}(10 \% \rightarrow 100 \%)$ to afford a main fraction $(199.6 \mathrm{mg}$ ), which was purified by silica CC (petroleum ether-EtOAc, 2:1) and semipreparative HPLC (Welch
Ultimate AQ- $\mathrm{C}_{18}, \mathrm{MeOH}-\mathrm{H}_{2} \mathrm{O}, 17: 83,2 \mathrm{~mL} / \mathrm{min}$ ) to yield 4 (8.3 $\mathrm{mg}, t_{\mathrm{R}}=50.308 \mathrm{~min}$ ).

Fraction $\mathrm{B} 4$ was subjected to $\mathrm{RP}-\mathrm{C}_{18}$ silica gel CC with $\mathrm{MeOH}-\mathrm{H}_{2} \mathrm{O}(10 \% \rightarrow 100 \%)$ to afford two main subfractions B4-1 and B4-2. Subfraction B4-1 (872.5 mg) was subjected to Sephadex LH-20 CC (MeOH) and was further purified by silica gel $\mathrm{CC}\left(\mathrm{CH}_{2} \mathrm{Cl}_{2}\right.$-acetone, 8:1) to yield $\mathbf{1 4}(8.3 \mathrm{mg})$. Subfraction B4-2 (696.4 mg) was subjected to Sephadex LH-20 CC (MeOH) and was further purified by silica gel CC $\left(\mathrm{CH}_{2} \mathrm{Cl}_{2}\right.$-acetone, $\left.8: 1\right)$ and semipreparative HPLC (Welch Ultimate AQ- $\mathrm{C}_{18}, \mathrm{MeOH}-\mathrm{H}_{2} \mathrm{O}, 45: 55,2 \mathrm{~mL} / \mathrm{min}$ ) to yield $15\left(24.4 \mathrm{mg}, t_{\mathrm{R}}=27.000 \mathrm{~min}\right)$.

\subsection{Spectroscopic Data of Compounds}

\subsubsection{Aquilarisinolide (1)}

White solid; $[\alpha]_{\mathrm{D}}^{27}+71(c 0.08, \mathrm{MeOH}) ; \mathrm{UV}(\mathrm{MeOH})$ $\lambda_{\max }(\log \varepsilon) 215(4.10) \mathrm{nm}$; ECD $(c 0.016, \mathrm{MeOH})$ : $\Delta \varepsilon_{219 \mathrm{~nm}}+5.06 ;{ }^{1} \mathrm{H}$ and ${ }^{13} \mathrm{C}$ NMR data, see Table 1; ESIMS $\mathrm{m} / z 259[\mathrm{M}+\mathrm{Na}]^{+} ;$HRESIMS $\mathrm{m} / z$ 259.1307 [M+ Na] ${ }^{+}$ (calcd for $\mathrm{C}_{14} \mathrm{H}_{20} \mathrm{NaO}_{3}, 259.1310$ ).

\subsection{2 (2R,4S,5R,7R)-2-Hydroxyeremophila-9, 11-dien-8-one} (2)

White solid; $[\alpha]_{\mathrm{D}}^{23}-79(c 0.12, \mathrm{MeOH})$; UV $(\mathrm{MeOH})$ $\lambda_{\max }(\log \varepsilon) 240(3.08) \mathrm{nm}$; ECD $(c 0.018, \mathrm{MeOH})$ : $\Delta \varepsilon_{239 \mathrm{~nm}}-6.83, \Delta \varepsilon_{201 \mathrm{~nm}}+7.36 ;{ }^{1} \mathrm{H}$ and ${ }^{13} \mathrm{C}$ NMR data, see Table 1; ESIMS $m / z 257[\mathrm{M}+\mathrm{Na}]^{+}$; HRESIMS $\mathrm{m} / \mathrm{z}$ $257.1512[\mathrm{M}+\mathrm{Na}]^{+}$(calcd for $\left.\mathrm{C}_{15} \mathrm{H}_{22} \mathrm{NaO}_{2}, 257.1518\right)$.

\subsection{3 (1R,4S,5S,7R,11R)-13-Hydroxydaphnau- ran-9-en-8-one (3)}

White solid; $[\alpha]_{\mathrm{D}}^{26}-37(c 0.07, \mathrm{MeOH}) ; \mathrm{UV}(\mathrm{MeOH}) \lambda_{\max }$ $(\log \varepsilon) 390$ (1.85), 246 (3.97), 201 (3.70) nm; ECD ( c 0.018, $\mathrm{MeOH}): \Delta \varepsilon_{322 \mathrm{~nm}}-3.78, \Delta \varepsilon_{249 \mathrm{~nm}}+12.15 ;{ }^{1} \mathrm{H}$ and ${ }^{13} \mathrm{C}$ NMR data, see Table 2; ESIMS $\mathrm{m} / z 257[\mathrm{M}+\mathrm{Na}]^{+}$; HRESIMS $m / z, 257.1516[\mathrm{M}+\mathrm{Na}]^{+}\left(\right.$calcd for $\left.\mathrm{C}_{15} \mathrm{H}_{22} \mathrm{NaO}_{2}, 257.1518\right)$.

\subsection{4 (4R,5S,7R,8S,10S,13R)-8,13-Dihydroxyro- tunda-1,11-dien-3-one (4)}

Yellow oil; $[\alpha]_{\mathrm{D}}^{27}-78(c 0.09, \mathrm{MeOH})$; UV (MeOH) $\lambda_{\max }$ $(\log \varepsilon) 237$ (3.87), 196 (3.73) nm; ECD (c 0.009, MeOH): $\Delta \varepsilon_{226 \mathrm{~nm}}-6.46, \Delta \varepsilon_{197 \mathrm{~nm}}+12.42$; IR $\nu_{\max }(\mathrm{KBr}) 3424,3071$, 2970, 2936, 2877, 1687, 1597, 1457, 1187, 1043, 1027, $975 \mathrm{~cm}^{-1}$; ${ }^{1} \mathrm{H}$ and ${ }^{13} \mathrm{C}$ NMR data, see Table 2; ESIMS $\mathrm{m} / \mathrm{z}$ 
$271[\mathrm{M}+\mathrm{Na}]^{+}$; HRESIMS $\mathrm{m} / z 271.1314[\mathrm{M}+\mathrm{Na}]^{+}(\mathrm{calcd}$ for $\mathrm{C}_{15} \mathrm{H}_{20} \mathrm{NaO}_{3}, 271.1310$ ).

\subsection{5 (5S,6S,7S,8R)-8-Chloro-2-(2-phenylethyl)-5,6,7-trihy- droxy-5,6,7,8-tetrahydrochromone (15)}

Yellow solid; $[\alpha]_{\mathrm{D}}^{26}+12(c 0.12, \mathrm{MeOH}) ; \mathrm{ECD}(c 0.009$, $\mathrm{MeOH}): \Delta \varepsilon_{305 \mathrm{~nm}}+0.32, \Delta \varepsilon_{232 \mathrm{~nm}}+1.33 ;$ ESIMS $m / z 359$ $[\mathrm{M}+\mathrm{Na}]^{+}, 695[2 \mathrm{M}+\mathrm{Na}]^{+}$.

\subsection{Computational Methods}

All DFT and TD-DFT calculations were carried out at $298 \mathrm{~K}$ in the gas phase with Gaussian 09 [21]. Conformational searches were carried out at the molecular mechanics level of theory employing MMFF force fields. The conformers with relative energy within $10 \mathrm{kcal} / \mathrm{mol}$ of the lowest-energy conformer were selected and further geometry optimized at the B3LYP/6-311+ + G (2d,p) level. All the lowest-energy conformers, which correspond to $99 \%$ of the total Boltzmann distribution, were selected for ECD spectra calculation. The Boltzmann factor for each conformer was calculated based on Gibbs free energy. Vibrational analysis at the B3LYP/6-311+ + G (2d, p) level of theory resulted in no imaginary frequencies, confirming the considered conformers as real minima. TDDFT was employed to calculate excitation energy (in $\mathrm{nm}$ ) and rotatory strength $\mathrm{R}$ in dipole velocity form, at the B3LYP/6-311+ + G (2d, p) level [22].

\subsection{Biological Assays}

\subsubsection{Corticosterone-Induced Damage in PC12 Cellular Assay}

Poorly differentiated PC12 cells (Cell Bank of Kunming Institute of Zoology, Chinese Academy of Sciences, Kunming, China) were maintained in DMEM supplemented with $10 \%$ fetal bovine serum (FBS), penicillin $(100 \mathrm{U} / \mathrm{mL})$, and streptomycin $(100 \mu \mathrm{g} / \mathrm{mL})$ and incubated with $5 \% \mathrm{CO}_{2}$ at $37^{\circ} \mathrm{C}$. The poorly differentiated $\mathrm{PC} 12$ cells were divided into the following groups: blank (untreated), negative control $(150 \mu \mathrm{M}$ CORT), positive control $(150 \mu \mathrm{M}$ CORT plus $10 \mu \mathrm{M}$ desipramine $)$, and compounds $(20 \mu \mathrm{M}$ of each tested compound plus $150 \mu \mathrm{M}$ CORT). Briefly, the poorly differentiated PC12 cells were seeded into 96-well culture plates at a density of $1 \times 10^{4}$ cells/well. After culturing for $24 \mathrm{~h}$, compounds were added to the wells. After $48 \mathrm{~h}$, MTS solution was added to each well. The absorbance was measured at $492 \mathrm{~nm}$ using a Thermo Multiskan FC [15].

\subsection{2 $\mathrm{MPP}^{+}$-Induced Damage in PC12 Cellular Assay}

Poorly differentiated PC12 cells were maintained in DMEM medium supplemented with $10 \%$ fetal bovine serum (FBS), penicillin $(100 \mathrm{U} / \mathrm{mL})$, streptomycin $(100 \mu \mathrm{g} / \mathrm{mL})$, and incubated at $5 \% \mathrm{CO}_{2}$ and $37^{\circ} \mathrm{C}$. The cells were divided into the following groups: blank (untreated), negative control $\left(750 \mu \mathrm{M} \mathrm{MPP}^{+}\right)$, positive control $(0.2 \mu \mathrm{M}$ vitamin E plus $\left.750 \mu \mathrm{M} \mathrm{MPP}{ }^{+}\right)$, and compounds $(20 \mu \mathrm{M}$ of each tested compound plus $750 \mu \mathrm{M} \mathrm{MPP}^{+}$). Briefly, poorly differentiated PC12 cells were seeded into 96-well culture plates at a density of $1 \times 10^{4}$ cells/well. After $23 \mathrm{~h}$ of culture, each compound or vitamin E was added to the wells. One hour later, $\mathrm{MPP}^{+}$was added. At $24 \mathrm{~h}$ after $\mathrm{MPP}^{+}$exposure, MTS was added; and two hours later, absorbance at $492 \mathrm{~nm}$ was read using a Thermo Multiskan FC.

\subsubsection{BACE1-Inhibitory Activity Assay}

The BACE-inhibitory assay was carried out according to the manufacturer described protocol available from SigmaAldrich [20]. Detection was based on fluorescence resonance energy transfer (FRET) technology, by which the enhanced fluorescence signal can be observed after the substrate is cleaved by BACE1. In the positive control group, $76 \mu \mathrm{L}$ of buffer, $20 \mu \mathrm{L}$ of $50 \mu \mathrm{M}$ BACE1 substrate solution, $2 \mu \mathrm{L}$ of 0.3 units/ $\mu \mathrm{L}$ BACE1 enzyme solution, and 2 $\mu \mathrm{L}$ of LY2886721 were added. The final concentration of LY2886721 was $0.2 \mu \mathrm{M}$. In the compound groups, $76 \mu \mathrm{L}$ of buffer, $20 \mu \mathrm{L}$ of $50 \mu \mathrm{M}$ BACE1 substrate solution, $2 \mu \mathrm{L}$ of 0.3 units/ $\mu \mathrm{L}$ BACE1 enzyme solution, and $2 \mu \mathrm{L}$ of tested sample solution were added. The final concentration of compounds was $20 \mu \mathrm{M}$. After adding the enzyme, the zero point of the fluorescence value (excitation $320 \mathrm{~nm}$, absorption $405 \mathrm{~nm}$ ) was measured immediately with FlexStation 3. Then, the plate was incubated for $2 \mathrm{~h}$ at $37^{\circ} \mathrm{C}$, and the fluorescence value was measured again by FlexStation 3 .

\section{Conclusion}

Four new and 13 known compounds were isolated from the resinous heartwood of $A$. sinensis. Six compounds showed significant protective effects on CORT-induced injury in PC1 2 cells, while one compound exhibited a significant protective effect on $\mathrm{MPP}^{+}$-induced injury in PC12 cells. These active compounds are worth further evaluation for neuroprotective activities.

Supplementary Information The online version contains supplementary material available at https://doi.org/10.1007/s13659-021-00313-0. 
Acknowledgements This study was supported by the National Natural Science Foundation of China (nos. 31960480, 81960629, 21662040, and 21462048) and the Joint Special Project of Local Undergraduate Universities in Yunnan Province, China (no. 2018FH001-024).

\section{Declarations}

Conflict of interest The authors declare that there are no conflicts of interest associated with this work.

Open Access This article is licensed under a Creative Commons Attribution 4.0 International License, which permits use, sharing, adaptation, distribution and reproduction in any medium or format, as long as you give appropriate credit to the original author(s) and the source, provide a link to the Creative Commons licence, and indicate if changes were made. The images or other third party material in this article are included in the article's Creative Commons licence, unless indicated otherwise in a credit line to the material. If material is not included in the article's Creative Commons licence and your intended use is not permitted by statutory regulation or exceeds the permitted use, you will need to obtain permission directly from the copyright holder. To view a copy of this licence, visit http://creativecommons.org/licenses/by/4.0/.

\section{References}

1. Editorial Board of Chinese Pharmacopoeia, Chinese Pharmacopoeia (China Medical Science Press, Beijing, 2020), Vol. 1, pp. 192-193

2. M. Gao, X. Han, Y. Sun, H. Chen, Y. Yang, Y. Liu, H. Meng, Z. Gao, Y. Xu, Z. Zhang, J. Han, RSC Adv. 9, 4113-4130 (2019)

3. A.N. Kristanti, M. Tanjung, N.S. Aminah, Mini-Rev. Org. Chem. 15, 36-55 (2018)

4. S. Wang, Z. Yu, C. Wang, C. Wu, P. Guo, J. Wei, Molecules 23, $342(2018)$

5. Q. He, D.-B. Hu, L. Zhang, M.-Y. Xia, H. Yan, X.-N. Li, J.-F. Luo, Y.-S. Wang, J.-H. Yang, Y.-H. Wang, Phytochemistry 181, 112554 (2021)
6. F.R. Chang, S.T. Huang, C.C. Liaw, M.H. Yen, T.L. Hwang, C.Y. Chen, M.F. Hou, S.S. Yuan, Y.B. Cheng, Y.C. Wu, Phytochemistry 131, 124-129 (2016)

7. S.Z. Huang, X.N. Li, Q.Y. Ma, H.F. Dai, L.C. Li, X.H. Cai, Y.Q. Liu, J. Zhou, Y.X. Zhao, Tetrahedron Lett. 55, 3693-3696 (2014)

8. S. Ahn, M. Chi Thanh, J.M. Choi, S. An, M. Lee, L. Van Thi Hong, J.J. Pyo, J. Lee, M.S. Choi, S.W. Kwon, J.H. Park, M. Noh, J. Nat. Prod. 82, 259-264 (2019)

9. T. Yagura, M. Ito, F. Kiuchi, G. Honda, Y. Shimada, Chem. Pharm. Bull. 51, 560-564 (2003)

10. K. Hashimoto, S. Nakahara, T. Inoue, Y. Sumida, M. Takahashi, Y. Masada, Chem. Pharm. Bull. 33, 5088-5091 (1985)

11. Y. Shimada, T. Tominaga, T. Konishi, S. Kiyosawa, Chem. Pharm. Bull. 30, 3791-3795 (1982)

12. K. Iwagoe, T. Konishi, S. Kiyosawa, Y. Shimada, K. Miyahara, T. Kawasaki, Chem. Pharm. Bull. 36, 2417-2422 (1988)

13. Y. Shimada, T. Konishi, S. Kiyosawa, M. Nishi, K. Miyahara, T. Kawasaki, Chem. Pharm. Bull. 34, 2766-2773 (1986)

14. T. Mukaiyama, T. Takuwa, K. Yamane, S. Imachi, Bull. Chem. Soc. Jpn. 76, 813-823 (2003)

15. B.P. Jiang, Y.M. Liu, L. Le, Z.Y. Li, J.Y. Si, X.M. Liu, Q. Chang, R.L. Pan, Cell. Physiol. Biochem. 34, 1015-1026 (2014)

16. L.L. Ji, X. Wang, J.J. Li, X.J. Zhong, B. Zhang, J. Juan, X.Y. Shang, Molecules 24, 625 (2019)

17. W. Liu, S. Kong, Q. Xie, J. Su, W. Li, H. Guo, S. Li, X. Feng, Z Su, Y. Xu, X. Lai, Int. J. Mol. Med. 35, 739-746 (2015)

18. K.H. Lin, C.Y. Li, Y.M. Hsu, C.H. Tsai, F.J. Tsai, C.H. Tang, J.S. Yang, Z.H. Wang, M.C. Yin, Food Chem. Toxicol. 133, 110765 (2019)

19. H. Hampel, R. Vassar, B. De Strooper, J. Hardy, M. Willem, N. Singh, J. Zhou, R. Yan, E. Vanmechelen, A. De Vos, Biol. Psychiatry 89, 745-756 (2021)

20. Sigma-Aldrich, https://www.sigmaaldrich.com/content/dam/ sigma-aldrich/docs/Sigma/Bulletin/cs0010bul.pdf. Accessed 8 April 2021

21. M.J. Frisch, Gaussian 09. Rev.Cl (M.J. Frisch, et al. Gaussian, Inc., Pittsburgh PA, 2009)

22. N.L. Tun, D.-B. Hu, M.-Y. Xia, D.-D. Zhang, J. Yang, T.N. Oo, Y.-H. Wang, X.-F. Yang, Nat. Prod. Bioprospect. 9, 243-249 (2019) 